\section{Capped Biscalix[4]arene-Zn-Porphyrin: Metalloreceptor with a Rigid Cavity}

\author{
Dmitry M. Rudkevich, Willem Verboom, and \\ David N. Reinhoudt*
}

Laboratory of Organic Chemistry, University of Twente,
P. O. Box 217, 7500 AE Enschede, The Netherlands

Received May 16, 1995

\section{Introduction}

Sterically hindered (e.g. strapped, capped, picket-fence, basket-handle, etc.) porphyrins are widely known as chemical models of metalloporphyrin-dependent proteins. ${ }^{1}$ Oxygen and carbon monoxide transport and storage by superstructured metalloporphyrins and mimicking of cytochrome P-450 and cytochrome $\mathrm{C}$ oxidase activity as well as electron transfer processes have been performed. ${ }^{2}$ Metalloporphyrins are also being used in supramolecular chemistry for recognition and catalysis. ${ }^{3}$ The complexation ability of $\mathrm{Zn}$-tetraarylporphyrins toward a wide variety of polar organic molecules and anions has been extensively studied. ${ }^{3-6}$ Immobilization of different binding sites (crown ethers, Kemp's triacid derivatives, xanthene skeleton, diamidopyridines, etc.) on the (metallo)porphyrin platform gives rise to specific sizeshape selectivity in substrate recognition. ${ }^{7}$ Recently Bonar-Law and Sanders ${ }^{8}$ reported large receptors in which a $\mathrm{Zn}$-porphyrin core was included into a large three-dimensional array of one or two cholic acid modules, bearing convergent hydroxyl groups, which showed strong binding of polyols, pyridines, imidazole, purine, etc. Cyclodextrin-capped porphyrins have been reported

(1) (a) Collman, J. P. Acc. Chem. Res. 1977, 10, 265-272. (b) Baldwin, J. P.; Perlmutter, P. Top. Curr. Chem. 1984, 121, 181-220. (c) Milgrom, L. R.; O'Neill, F. In: The Chemistry of Natural Products, 2nd ed.; Thomson, R. H., Ed.; Blackie Academic \& Professional: London, 1993; pp 329-381.

(2) For general reviews see: (a) Momenteau, M.; Reed, C. A. Chem. Rev. 1994, 94, 659-698. (b) Collman, J. P.; Zhang, X.; Lee, V. J.; Uffelman, E. S.; Brauman, J. I. Science 1993, 261, 1404-1411. (c) Gribkova, S. E.; Evstigneeva, R. P.; Luzgina, V. N. Russ. Chem. Rev 1993, 62, 963-979. (d) Ma, W.; Slebodnick, C.; Ibers, J. A. J. Org. Chem. 1993, 58,6349-6353 and references cited therein.

(3) For recent reviews see: (a) Sutherland, I. O. In Advances in Supramolecular Chemistry; Gokel, G. W., Ed.; JAI Press Inc.: London, 1990; Vol. 1, pp 65-108. (b) Aoyama, Y. In Advances in Supramolecular Chemistry; Gokel, G. W., Ed.; JAI Press Inc.: London, 1992; Vol. 2, pp 65-92. (c) Kuroda, Y.; Ogoshi, H. Synlett 1994, 319-324. (d) BonarLaw, R. P.; Mackay, L. G.; Walter, C. J.; Marvaud, V.; Sanders, J. K. M. Pure Appl. Chem. 1994, 66, 803-810.

(4) Nappa, M.; Valentine, J. S. J. Am. Chem. Soc. 1978, 100, 50755080

(5) (a) Danks, I. P.; Sutherland, I. O.; Yap, C. H. J. Chem. Soc., Perkin Trans. 1 1990, 421-422. (b) Hunter, C. A.; Meah, M. N. Sanders, J. K. M. J. Am. Chem. Soc. 1990, 112, 5773-5780. (c) Anderson, H. L.; Hunter, C. A.; Meah, M. N.; Sanders, J. K. M. J. Am. Chem. Soc. 1990, 112, 5780-5789. (d) Danks, I. P.; Lane, T. G. Sutherland, I. O.; Yap, M. Tetrahedron 1992, 48, 7679-7688.

(6) (a) Benson, D. R.; Valentekovich, R.; Knobler, C. B.; Diederich, F. Tetrahedron 1991, 47, 2401-2422. (b) Mizutani, T.; Ema, T.; Tomita, T.; Kuroda, Y.; Ogoshi, H. J. Am. Chem. Soc. 1994, 116, 4240-4250. (c) Imada, T.; Kijima, H.; Takeuchi, M.; Shinkai, S. Tetrahedron Lett. 1995, 36, 2093-2096

(7) (a) Hamilton, A. D.; Lehn, J.-M.; Sessler, J. L. J. Am. Chem. Soc. 1986, 108, 5158-5167. (b) Lindsey, J. S.; Kearney, P. C.; Duff, R. J; Tjivikua, P. T.; Rebek, J., Jr. J. Am. Chem. Soc. 1988, 110, 65756577. (c) Slobodkin, G.; Fan, E.; Hamilton, A. D. New J. Chem. 1992 16, 643-645. (d) Shipps, G., Jr.; Rebek, J., Jr. Tetrahedron Lett. 1994 $35,6823-6826$.

(8) (a) Bonar-Law, R. P.; Sanders, J. K. M. J. Chem. Soc., Chem. Commun. 1991, 574-577. (b) Bonar-Law, R. P.; Sanders, J. K. M. J Am. Chem. Soc. 1995, 117, 259-271. to exhibit pronounced P-450 like activity and photoinduced electron transfer toward quinones. ${ }^{9}$

Our approach to the construction of large receptor structures is based on the proper covalent combination of different, readily available supramolecular building blocks (e.g. calixarenes, cavitands, crown ethers, cyclodextrins, etc.) in one molecule. ${ }^{10,11}$ Recently we have prepared large and multifunctional U-shaped metalloreceptors in which two calix[4]arene fragments are attached to a $\mathrm{Zn}$-tetraarylporphyrin moiety. ${ }^{12,13}$ In this paper we report the synthesis and complexation behavior of large metalloreceptor 1 in which the active $\mathrm{Zn}-$ porphyrin core is for the first time covalently incorporated into a hydrophobic and rigid "egg-shaped" bis-calix[4]arene cavity, providing both effective shielding and encapsulation of a substrate from the environment.

\section{Results and Discussion}

The synthesis of biscalix[4]arene-Zn-porphyrin 1 is depicted in Scheme 1. Calixarene 3 which has two aldehyde moieties at the upper rim was obtained by reaction of 1,3-bis(chloroacetamido)tetrapropoxycalix [4]arene ${ }^{10} 2$ with $o$-hydroxybenzaldehyde in refluxing $\mathrm{MeCN}$ using $\mathrm{K}_{2} \mathrm{CO}_{3}$ as a base in $67 \%$ yield. Stirring of 3 with an excess of pyrrole ${ }^{14}$ gave the (relatively) unstable bis(dipyrrolylmethane) 4 in 55\% yield. Compound 4 easily reacts with its precursor 3 in $\mathrm{CHCl}_{3}$ in the presence of a catalytic amount of $\mathrm{BF}_{3} \cdot \mathrm{Et}_{2} \mathrm{O}$ forming, after oxidation with DDQ, free base porphyrin 5 in $5 \%$ yield. The positive ion FAB mass spectrum of compound 5 shows a peak at $m / z 2084.8$ with an intensity of ca. $96 \%$, which corresponds to a structure containing one porphyrin and two calix[4]arene moieties.

$\mathrm{Zn}$-complex 1 was prepared in a quantitative yield by refluxing free base porphyrin 5 with $\mathrm{Zn}(\mathrm{OAc})_{2} \cdot 2 \mathrm{H}_{2} \mathrm{O}$ in $\mathrm{CHCl}_{3}-\mathrm{MeOH}, 2: 1$. The positive ion FAB mass spectrum of 1 shows an intense (ca. 95\%) peak at 2147.9 which corresponds to the proposed structure. The ${ }^{1} \mathrm{H}$ NMR spectrum of 1 in $\mathrm{CDCl}_{3}$ exhibits a characteristic singlet for the porphyrin ring at $8.68 \mathrm{ppm}$. The calix[4]arene methylene bridge $\mathrm{CH}_{2}$-region consists of two doublets with equal intensities at 4.13 and $2.84 \mathrm{ppm}(J=13.0$ $\mathrm{Hz}$ ) which implies a high symmetry of the molecule with the porphyrin fragment centered in between two calix[4]arene fragments.

Biscalix[4]arene- $\mathrm{Zn}$-porphyrin 1 is an attractive model for molecular recognition. Besides the active metallo-

(9) (a) Kuroda, Y.; Hiroshige, T.; Sera, T.; Shiroiwa, Y.; Tanaka, H.; Ogoshi, H. J. Am. Chem. Soc. 1989, 111, 1912-1913. (b) Kuroda, Y.; Ito, M.; Sera, T.; Ogoshi, H. J. Am. Chem. Soc. 1993, 115, 7003-7004. (c) Kuroda, Y.; Egawa, Y.; Seshimo, H.; Ogoshi, H. Chem. Lett. 1994, $2361-2364$.

(10) Rudkevich, D. M.; Verboom, W.; Reinhoudt, D. N. J. Org. Chem. 1994, 59, 3683-3686.

(11) (a) van Dienst, E.; Iwema Bakker, W. I.; Engbersen, J. F. J.; Verboom, W.; Reinhoudt, D. N. Pure Appl. Chem. 1993, 65, 387-392. (b) Timmerman, P.; Verboom, W.; van Veggel, F. C. J. M.; van Hoorn, W. P.; Reinhoudt, D. N. Angew. Chem., Int. Ed. Engl. 1994, 33, 12921295. (c) Rudkevich, D. M.; Brzozka, Z.; Palys, M.; Visser, H. C. Verboom, W.; Reinhoudt, D. N. Angew. Chem., Int. Ed. Engl. 1994, 33, 467-468. (d) Rudkevich, D. M.; Mercer-Chalmers, J. D.; Verboom, W.; Ungaro, R.; de Jong, F.; Reinhoudt, D. N. J. Am. Chem. Soc. 1995, $117,6124-6125$

(12) Rudkevich, D. M.; Verboom, W.; Reinhoudt, D. N. Tetrahedron Lett. 1994, 35, 7131-7134.

(13) For other approaches to combine calix[4]arene and (metallo) porphyrin building blocks see: (a) Asfari, Z.; Vicens, J.; Weiss, J Tetrahedron Lett. 1993, 34, 627-628. (b) Nagasaki, T.; Fujishima, H.; Shinkai, S. Chem. Lett. 1994, 989-992. (c) Kobayashi, N.; Mizuno, K.; Osa, T. Inorg. Chim. Acta 1994, 224, 1-3.

(14) Lee, C.-H.; Lindsey, J. S. Tetrahedron 1994, 50, 11427-11440. 
Scheme 1

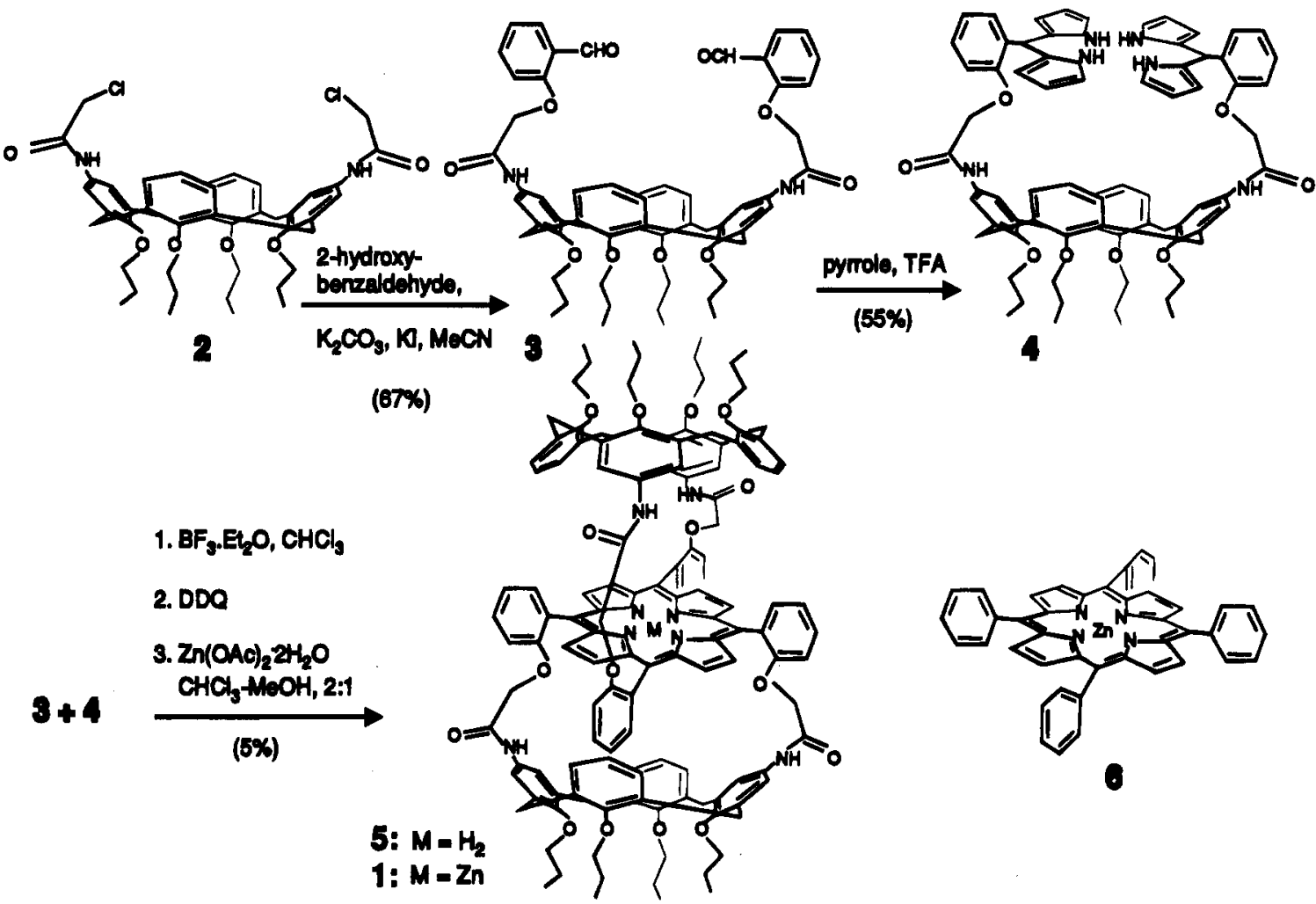

Table 1. Association Constants $K_{\text {ass }}\left(M^{-1}\right)$ and Binding Energies $\Delta G\left(k_{J} J M^{-1}\right)$ for Porphyrins 1 and $6^{a}$

\begin{tabular}{llllll}
\hline \multirow{2}{*}{ Guest } & \multicolumn{2}{c}{1} & \multicolumn{2}{c}{6} \\
\cline { 2 - 3 } \cline { 5 - 6 } \cline { 5 - 6 } & \multicolumn{1}{c}{$K_{\text {ass }}$} & $-\Delta G$ & & \multicolumn{1}{c}{$K_{\text {ass }}$} & $-\Delta G$ \\
\hline pyridine & $1.1 \times 10^{4}$ & 22.7 & $9.2 \times 10^{2}$ & 16.6 \\
4-methylpyridine & $>10^{6}$ & $>33.0$ & & $1.6 \times 10^{3}$ & 18.0 \\
4-tert-butylpyridine & $b$ & $b$ & $3.0 \times 10^{3}$ & 19.5 \\
piperidine & $7.9 \times 10^{3}$ & 21.9 & $1.2 \times 10^{3}$ & 17.3 \\
$N$-methylimidazole & $>10^{6}$ & $>33.0$ & $1.5 \times 10^{4}$ & 23.4
\end{tabular}

${ }^{a}$ Measured in $\mathrm{CDCl}_{3}$ at $293 \mathrm{~K} .{ }^{b}$ No binding was observed.

center this receptor contains two lipophilic calix[4]arene fragments serving as additional binding sites. Moreover, the two cavities (formed by one porphyrin and both calix[4]arene units) of ca. $8 \AA$ (from CPK models) each are able to shield a guest (substrate) from the environment.

$\mathrm{Zn}$-porphyrins are known to bind only one axial ligand resulting in a five-coordinated zinc atom. ${ }^{4,15}$ In order to demonstrate the ability of biscalix[4]arene-Zn-porphyrin 1 to incorporate polar neutral substrates into the cavity, binding studies were performed in $\mathrm{CDCl}_{3}$ with pyridine derivatives, piperidine, and $N$-methylimidazole. For comparison, analogous experiments with unsubstituted and unshielded $\mathrm{Zn}$-tetraphenylporphyrin 6 were also performed. Association constants $K_{\text {ass }}$ and binding energies $-\Delta G$ for $1: 1$ complexation obtained from titration experiments (see Experimental Section) are collected in Table $1 .^{16}$

As it follows from Table 1, receptor 1 binds the guests studied (except 4-tert-butylpyridine) ca. 10-1000 times stronger than unsubstituted porphyrin 6. In particular, binding of 4-methylpyridine and $N$-methylimidazole is

(15) (a) Miller, J. R.; Dorough, G. D. J. Am. Chem. Soc. 1952, 74, 3977-3981. (b) Hambright, P. J. Chem. Soc., Chem. Commun. 1967, $470-471$

(16) UV-vis experiments with 1 in $\mathrm{CH}_{2} \mathrm{Cl}_{2}$ also showed a strong binding of substrates studied; a bathochromic shift of the Soret band of $8 \mathrm{~nm}$ was found upon addition of already 1 equiv of a guest. very strong with $K_{\text {ass }}$ values $>10^{6} \mathrm{M}^{-1}(-\Delta G>33.0 \mathrm{~kJ}$ $\left.\mathrm{M}^{-1}\right)$. The ${ }^{1} \mathrm{H}$ NMR spectra of 1 showed systematic upfield shifts (ca. $0.10-0.12 \mathrm{ppm}$ ) for the porphyrin protons upon addition of a guest. In the case of $N$ methylimidazole a kinetically (on the NMR time-scale) stable complex was detected as inferred from two separate sets of signals for both the free host 1 and the complex. In the case of 4-tert-butylpyridine no complexation was found for receptor 1 , although it is bound by porphyrin $6\left(K_{\mathrm{ass}}=3.0 \times 10^{3} \mathrm{M}^{-1}\right)$. Apparently the sterically bulky 4-tert-butylpyridine is too large to enter one of the cavities of 1 .

These results clearly demonstrate the role of the rigid cavities in 1 which are capable of effective shielding of a guest and also provide additional hydrophobic binding strength upon guest complexation. Stepwise addition of a guest solution to a solution of 1 results in a significant upfield shift of $0.2-0.4 \mathrm{ppm}$ for the acetamido $\mathrm{CH}_{2} \mathrm{C}(\mathrm{O})$ protons. The aromatic signals of the calix[4]arene moieties undergo broadening to 1 equiv of added guest solution which clearly indicates that guest molecules do enter the cavity. Moreover, the ${ }^{1} \mathrm{H}$ NMR spectra of the complexes $1 \cdot N$-methylimidazole and 1.4-methylpyridine show pronounced upfield shifts for the $\mathrm{CH}_{3}$-groups of the guests at -0.39 and $-2.60 \mathrm{ppm}$, respectively (uncomplexed $N$-methylimidazole and 4-methylpyridine exhibit corresponding signals at 3.63 and $2.31 \mathrm{ppm}$, respectively), which demonstrates the shielding effect of the cavity and also explains the extremely strong binding of these guests in comparison with the others (Table 1). ${ }^{17}$ Most probably, the $\mathrm{CH}_{3}$-groups of complexed $N$-methylimidazole and 4-methylpyridine are situated inside the calix[4]arene

(17) For recent reviews on incarceration of guests within hydrophobic cavities see: (a) Cram, D. J.; Cram, J. M. Container Molecules and their Guests; Monographs in Supramolecular Chemistry; Stoddart, J. F., Ed.; The Royal Society of Chemistry: Cambridge, 1994; Vol. 4. (b) Sherman, J. C. Tetrahedron 1995, 51, 3395-3422. 
cavity as known ${ }^{18}$ for calix[4]arene complexes with methylbenzenes.

In conclusion, we have demonstrated that doubly calix[4]arene capped porphyrin 1 is an excellent receptor for different aza-heterocycles, in addition to shielding due to the ideal combination of the properties of both building blocks. Currently we are studying capped biscalix[4]arene porphyrins (as cobalt and iron complexes) for oxygen transport and storage.

\section{Experimental Section}

Melting points are uncorrected. ${ }^{1} \mathrm{H}$ NMR spectra were recorded in $\mathrm{CDCl}_{3}$ with $\mathrm{Me}_{4} \mathrm{Si}$ as internal standard. Fast atom bombardment (FAB) mass spectra were obtained with $m$ nitrobenzyl alcohol as a matrix. All solvents were purified by standard procedures. Petroleum ether refers to the fraction with bp $60-80^{\circ} \mathrm{C}$. All other chemicals were analytically pure and were used without further purification. Compound 2 was prepared according to a literature procedure ${ }^{10}$ and compound 6 was obtained from Aldrich. All reactions were carried out under a nitrogen atmosphere. The presence of solvent in the analytical samples was confirmed by ${ }^{1} \mathrm{H}$ NMR spectroscopy.

5,17-Bis[(2-formylphenoxy)acetamido]-25,26,27,28tetrapropoxycalix[4]arene (3). A mixture of 1,3-bis(chloroacetamido)tetrapropoxycalix[4]arene $\mathrm{e}^{10} 2(2.00 \mathrm{~g}, 2.6 \mathrm{mmol})$, 2-hydroxybenzaldehyde $(0.63 \mathrm{~g}, 5.2 \mathrm{mmol}), \mathrm{K}_{2} \mathrm{CO}_{3}(0.71 \mathrm{~g}, 5.2$ $\mathrm{mmol}$ ), and potassium iodide (0.17 $\mathrm{g}, 1 \mathrm{mmol}$ ) in MeCN (150 $\mathrm{mL}$ ) was refluxed for $2 \mathrm{~h}$. After filtration the solvent was removed and the crude product was purified by column chromatography [neutral $\mathrm{Al}_{2} \mathrm{O}_{3}$ (activity I), EtOAc] to afford 3 as a pale yellow solid: yield $67 \% ; \mathrm{mp} 126-127^{\circ} \mathrm{C}\left(\mathrm{CH}_{2} \mathrm{Cl}_{2}\right.$ /petroleum ether); ${ }^{1} \mathrm{H}$ NMR $\delta 10.05(\mathrm{~s}, 2 \mathrm{H}), 9.32(\mathrm{br} \mathrm{s}, 2 \mathrm{H}), 7.61$ (d, $2 \mathrm{H}, J$ $=7.5 \mathrm{~Hz}), 7.43(\mathrm{t}, 2 \mathrm{H}, J=7.5 \mathrm{~Hz}), 7.34(\mathrm{~s}, 4 \mathrm{H}), 6.95(\mathrm{t}, 2 \mathrm{H}, J$ $=7.5 \mathrm{~Hz}), 6.81(\mathrm{~d}, 2 \mathrm{H}, J=7.5 \mathrm{~Hz}), 6.55-6.45(\mathrm{~m}, 6 \mathrm{H}), 4.53$, $3.22(2 \times \mathrm{d}, 8 \mathrm{H}, J=13.0 \mathrm{~Hz}), 4.47(\mathrm{~s}, 4 \mathrm{H}), 3.92,3.80(2 \times \mathrm{t}, 8$ $\mathrm{H}, J=7.0 \mathrm{~Hz}), 2.1-1.9(\mathrm{~m}, 8 \mathrm{H}), 1.12,1.04(2 \times \mathrm{t}, 12 \mathrm{H}, J=7.0$ $\mathrm{Hz}$ ); MS-FAB $m / z 947.0\left(\mathrm{M}^{+}\right.$, calcd 947.1). Anal. Calcd for $\mathrm{C}_{58} \mathrm{H}_{62} \mathrm{~N}_{2} \mathrm{O}_{10} .0 .5 \mathrm{H}_{2} \mathrm{O} ; \mathrm{C}, 72.86 ; \mathrm{H}, 6.64 ; \mathrm{N}, 2.93$. Found: $\mathrm{C}$, $73.15 ; \mathrm{H}, 6.72 ; \mathrm{N}, 2.94$.

5,17-Bis[(2-phenoxydipyrrolylmethane)acetamido]-25,26,27,28-tetrapropoxycalix [4]arene (4). A solution of dialdehyde 3 (4.80 g, $5.1 \mathrm{mmol})$ in pyrrole $(27.00 \mathrm{~g}, 400 \mathrm{mmol})$ was degassed by bubbling with nitrogen for $10-15 \mathrm{~min}$, and then $\mathrm{CF}_{3} \mathrm{COOH}(0.04 \mathrm{~mL}, 0.5 \mathrm{mmol})$ was added. The solution was stirred for $0.5 \mathrm{~h}$ at rt, diluted with $\mathrm{CH}_{2} \mathrm{Cl}_{2}(100 \mathrm{~mL})$, washed with 0.1 aqueous $\mathrm{NaOH}(2 \times 100 \mathrm{~mL})$ and water $(2 \times 100 \mathrm{~mL})$, and evaporated. Purification by column chromatography (silica gel, EtOAc-petroleum ether-E $\mathrm{t}_{3} \mathrm{~N}, 10: 20: 0.3$ ) afforded pure 4 as a colorless oil: yield $55 \% ;{ }^{1} \mathrm{H}$ NMR $\delta 8.88(\mathrm{br} \mathrm{s}, 4 \mathrm{H}), 7.43(\mathrm{br}$ $\mathrm{s}, 2 \mathrm{H}), 7.16(\mathrm{t}, 2 \mathrm{H}, J=7.5 \mathrm{~Hz}), 7.14(\mathrm{~d}, 2 \mathrm{H}, J=7.5 \mathrm{~Hz}), 6.95$ $(\mathrm{t}, 2 \mathrm{H}, J=7.5 \mathrm{~Hz}), 6.90(\mathrm{~d}, 4 \mathrm{H}, J=8.0 \mathrm{~Hz}), 6.85-6.80,6.15-$

(18) Gutsche, C. D. Calixarenes; Monographs in Supramolecular Chemistry; Stoddart, J. F., Ed.; The Royal Society of Chemistry: London, 1989; Vol. 1.
$6.10,5.85-5.80(3 \times \mathrm{m}, 12 \mathrm{H}), 6.55(\mathrm{t}, 2 \mathrm{H}, J=8.0 \mathrm{~Hz}), 6.38(\mathrm{~s}$, $4 \mathrm{H}), 6.32(\mathrm{~d}, 2 \mathrm{H}, J=7.5 \mathrm{~Hz}), 5.62(\mathrm{~s}, 2 \mathrm{H}), 4.45,3.13(2 \times \mathrm{d}$, $8 \mathrm{H}, J=13.0 \mathrm{~Hz}), 3.98(\mathrm{~s}, 4 \mathrm{H}), 3.95,3.65(2 \times \mathrm{t}, 8 \mathrm{H}, J=7.0$ $\mathrm{Hz}), 2.1-1.8(\mathrm{~m}, 8 \mathrm{H}), 1.12,0.91(2 \times \mathrm{t}, 12 \mathrm{H}, J=7.0 \mathrm{~Hz})$; MS$\mathrm{FAB} m / z 1177.2\left[(\mathrm{M}-2 \mathrm{H})^{-}\right.$, calcd for $\left.\mathrm{C}_{74} \mathrm{H}_{78} \mathrm{~N}_{6} \mathrm{O}_{8} 1177.5\right]$. Due to (slow) decomposition, elemental analysis cannot be performed.

5,15:10,20-Bis[15,17-(25,26,27,28-tetrapropoxycalix[4]arenediyl)bis[2-carbamoylmethoxy)phenyl]]porphyrin (5). A solution of $4(1.50 \mathrm{~g}, 1.23 \mathrm{mmol})$ and dialdehyde $3(1.16 \mathrm{~g}$, $1.23 \mathrm{mmol})$ in $\mathrm{CHCl}_{3}(900 \mathrm{~mL})$ was saturated with nitrogen for $15 \mathrm{~min}$, and then 3 drops of $\mathrm{BF}_{3} \cdot \mathrm{Et}_{2} \mathrm{O}$ were added. The solution was stirred for $1 \mathrm{~h}$ at $\mathrm{rt}$ whereupon DDQ $(0.54 \mathrm{~g}, 2.46 \mathrm{mmol})$ was added. After the mixture was stirred at $\mathrm{rt}$ for $1 \mathrm{~h}$ the solvent was evaporated. Column chromatography (silica gel, $\mathrm{CH}_{2} \mathrm{Cl}_{2}-$ $\left.\mathrm{Et}_{2} \mathrm{O}, 30: 1 \rightarrow 10: 1\right)$ gave pure free base porphyrin 5 as a pink solid which was directly submitted to metalation. Yield $5 \% ; \mathrm{mp}$ $>300{ }^{\circ} \mathrm{C} ;{ }^{1} \mathrm{H}$ NMR $\delta 8.69(\mathrm{~s}, 8 \mathrm{H}), 8.65(\mathrm{~d}, 4 \mathrm{H}, J=7.5 \mathrm{~Hz}), 7.72$ $(2 \times \mathrm{t}, 8 \mathrm{H}, J=7.5 \mathrm{~Hz}), 7.19(\mathrm{~d}, 4 \mathrm{H}, J=7.5 \mathrm{~Hz}), 6.72(\mathrm{~d}, 8 \mathrm{H}$, $J=7.9 \mathrm{~Hz}), 6.51(\mathrm{~s}, 4 \mathrm{H}), 6.50(\mathrm{t}, 4 \mathrm{H}, J=7.9 \mathrm{~Hz}), 6.23(\mathrm{~s}, 8 \mathrm{H})$, $4.23,2.91(2 \times \mathrm{d}, 16 \mathrm{H}, J=13.0 \mathrm{~Hz}), 3.9-3.7(\mathrm{~m}, 8 \mathrm{H}), 3.60(\mathrm{~s}$, $8 \mathrm{H}), 3.40(\mathrm{t}, 8 \mathrm{H}, J=7.5 \mathrm{~Hz}), 2.1-1.8(2 \times \mathrm{m}, 16 \mathrm{H}), 0.95,0.83$ $(2 \times \mathrm{t}, 24 \mathrm{H}, J=7.5 \mathrm{~Hz}),-2.24(\mathrm{br} \mathrm{s}, 2 \mathrm{H}) ; \mathrm{MS}-\mathrm{FAB} \mathrm{m} / z 2084.8$ $\left(\mathrm{M}^{+}\right.$, calcd 2084.5). Anal. Calcd for $\mathrm{C}_{132} \mathrm{H}_{130} \mathrm{~N}_{8} \mathrm{O}_{16} .4 \mathrm{H}_{2} \mathrm{O}$ : C, $73.52 ; \mathrm{H}, 6.45 ; \mathrm{N}, 5.20$. Found: $\mathrm{C}, 73.41 ; \mathrm{H}, 6.85 ; \mathrm{N}, 5.24$.

[5,15:10,20-Bis[15,17-(25,26,27,28-tetrapropoxycalix[4]arenediyl)bis[2-(carbamoylmethoxy)phenyl]]porphyrin]zinc(II) (1). A mixture of free base porphyrin $5(0.10 \mathrm{~g}, 0.05$ $\mathrm{mmol})$ and $\mathrm{Zn}(\mathrm{OAc})_{2} \cdot 2 \mathrm{H}_{2} \mathrm{O}(0.015 \mathrm{~g}, 0.07 \mathrm{mmol})$ was refluxed in $\mathrm{CHCl}_{3}-\mathrm{MeOH}, 2: 1(15 \mathrm{~mL})$ for $3 \mathrm{~h}$. After evaporation of the solvent, the residue was redissolved in $\mathrm{CH}_{2} \mathrm{Cl}_{2}(15 \mathrm{~mL})$ and washed with water $(2 \times 25 \mathrm{~mL})$. Evaporation of the solvent gave pure 1 as a dark red solid in a quantitative yield. An analytical sample was additionally purified by preparative TLC (silica gel, $\left.\mathrm{CH}_{2} \mathrm{Cl}_{2}-\mathrm{Et}_{2} \mathrm{O}, 10: 1\right) . \mathrm{Mp}>300{ }^{\circ} \mathrm{C}$; UV-vis $\left(\mathrm{CH}_{2} \mathrm{Cl}_{2}\right) \lambda_{\max } 422$ $\mathrm{nm} ;{ }^{1} \mathrm{H}$ NMR $\& 8.68(\mathrm{~s}, 8 \mathrm{H}), 8.49(\mathrm{~d}, 4 \mathrm{H}, J=7.5 \mathrm{~Hz}), 7.65,7.57$ $(2 \times t, 8 \mathrm{H}, J=7.5 \mathrm{~Hz}), 7.14(\mathrm{~d}, 4 \mathrm{H}, J=7.5 \mathrm{~Hz}), 6.63(\mathrm{~d}, 8 \mathrm{H}$, $J=7.9 \mathrm{~Hz}), 6.50(\mathrm{~s}, 4 \mathrm{H}), 6.35(\mathrm{t}, 4 \mathrm{H}, J=7.9 \mathrm{~Hz}), 6.19(\mathrm{~s}, 8 \mathrm{H})$, $4.13,2.84(2 \times \mathrm{d}, 16 \mathrm{H}, J=13.0 \mathrm{~Hz}), 3.8-3.7(\mathrm{~m}, 8 \mathrm{H}), 3.59(\mathrm{~s}$, $8 \mathrm{H}), 3.35(\mathrm{t}, 8 \mathrm{H}, J=7.5 \mathrm{~Hz}), 2.0-1.8(2 \times \mathrm{m}, 16 \mathrm{H}), 0.85,0.76$ $(2 \times \mathrm{t}, 24 \mathrm{H}, J=7.5 \mathrm{~Hz}) ; \mathrm{MS}-\mathrm{FAB} m / z 2147.9\left(\mathrm{M}^{+}\right.$, calcd 2147.9$)$. Anal. Calcd for $\mathrm{C}_{132} \mathrm{H}_{128} \mathrm{~N}_{8} \mathrm{O}_{16} \mathrm{Zn} \cdot 3 \mathrm{CH}_{2} \mathrm{Cl}_{2}: \mathrm{C}, 67.49 ; \mathrm{H}, 5.62 ; \mathrm{N}$, 4.69. Found: C, $67.54 ; \mathrm{H}, 5.73 ; \mathrm{N}, 4.44$.

Determination of Association Constants. The measurements were performed by ${ }^{1} \mathrm{H}$ NMR titration experiments in $\mathrm{CDCl}_{3}$ at $293 \mathrm{~K}$ using a constant concentration of hosts 1 and 6 of $0.2-0.8 \mathrm{mM}$ and a varying guest concentration of $0.05-25$ $\mathrm{mM}$. The chemical shifts of the pyrrole units or the $\mathrm{CH}_{2} \mathrm{C}(\mathrm{O})$ spacers of 1 were used as a probe. The $K_{\text {ass }}$ values were obtained with a nonlinear two-parameter fit of the chemical shift and the association constant. ${ }^{19}$ The results gave good fits for a typical 1:1 stoichiometry as could be concluded from the function values. ${ }^{19}$ The estimated error is $5 \%$.

\section{J09507909}

(19) De Boer, J. A. A.; Reinhoudt, D. N.; Harkema, S.; van Hummel, G. J.; de Jong, F. J. Am. Chem. Soc. 1982, 104, 4073-4076. 